\title{
Effectiveness of the GAEC standard of cross compliance retain terraces on soil erosion control
}

\author{
Paolo Bazzoffi, ${ }^{1}$ Lorenzo Gardin² \\ ${ }^{1}$ CRA-ABP Agricultural Research Council, Agrobiology and Pedology Research Centre, Firenze; \\ ${ }^{2}$ Agronomist, freelancer, Firenze, Italy
}

\begin{abstract}
The GAEC standard retain terraces of cross compliance prohibits farmers the elimination of existing terraces, with the aim to ensure the protection of soil from erosion. In the Italian literature there are not field studies to quantify the effects of the elimination or degradation of terraces on soil erosion. Therefore, the modeling approach was chosen and applied in a scenario analysis to evaluate increasing levels of degradation of stone wall terraces. The study was conducted on two sample areas: Lamole (700.8 ha, Tuscany) and Costaviola (764.73 ha, Calabria) with contrasting landscapes. The Universal Soil Loss Equation model (USLE) was applied in the comparative assessment of the soil erosion risk ( $\mathrm{Mg}$. $\left.\mathrm{ha}^{-1} \cdot \mathrm{yr}^{-1}\right)$, by simulating five increasing intensity of terrace degradation, respectively: conserved partially damaged, very damaged, partially removed, removed, each of which corresponding to different values of the indexes of verification in case of infringement to GAEC standard provided for by the AGEA rules which have come into force since December 2009 (Agency for Agricultural Payments). To growing intensity of degradation, a progressive loss of efficacy of terraces was attributed by increasing the values of the LS factor (length and slope) of USLE in relation with the local modification of the length and steepness of the slope between adjacent terraces. Basically, it was simulated the gradual return to the
\end{abstract}

Correspondence: Paolo Bazzoffi, CRA-ABP Agricultural Research Council, Agrobiology and Pedology Research Centre, p.zza M. D’Azeglio 30, 50121 Firenze, Italy.

Tel. +39.055.2491228 - Fax: +39.055 .241485 .

E-mail: paolo.bazzoffi@entecra.it

Key words: soil erosion, stone wall terraces, gaec standard, cross-compliance.

Acknowledgements: we greatly acknowledge Massimo Aglietti, of the CRAABP staff, for the peer review of the text in English.

Contribution: the authors contributed equally to the research.

Received for publication: 24 March 2011.

Accepted for publication: 4 May 2011.

(C) Copyright P. Bazzoffi and L. Gardin, 2011

Under no circumstances figures can be used without prior written consent of the copyright owner.

Licensee PAGEPress, Italy

Italian Journal of Agronomy 2011; 6(s1):e6

doi:10.4081/ija.2011.6.s1.e6

This work is licensed under a Creative Commons Attribution NonCommercial 3.0 License (CC BY-NC 3.0). natural morphology of the slope. The results of the analysis showed a significant increase in erosion in relationship with increasing degradation of terraces. Furthermore, it is possible to conclude that the GAEC standard retain terraces is very effective with regard to the primary objective of reducing erosion. A further statistical analysis was performed to test the protective value of terraces against soil erosion in areas where agriculture was abandoned. The analysis was carried out by comparing the specific risk of erosion $\left(\mathrm{Mg} \cdot \mathrm{ha}^{-1} \cdot \mathrm{yr}^{-1}\right)$ of polygons with land uses: forest and abandoned, with natural vegetation in evolution. In both areas, forest on totally degraded terraces is able to decrease erosion well below the tolerance threshold of $11.2 \mathrm{Mg} \cdot \mathrm{ha}^{-1} \cdot \mathrm{yr}^{-1}$, in the same manner as conserved terraces do for other soil uses. At Lamole, the natural vegetation in evolution on completely degraded terraces is able to decrease erosion below the tolerance threshold. On the contrary, at Costaviola on the same soil use and level of terrace degradation, soil erosion remained above the tolerance threshold. This difference can be explained by considering that the average gradient of hillslopes (considered without terraces) is $65.4 \%$ for Costaviola and $35.0 \%$ for Lamole. From these findings it is possible to argue that terraces, although degraded, continue to play a role in the protection of soil against erosion in abandoned areas. Thus, they continue to exert a valuable environmental function in terms of production of public goods and services; in particular, in the decrease of hydrogeological risk.

\section{Introduction}

\section{Legislation and goal of the study}

GAECs (Standards of Good Agricultural and Environmental Condition) form part of the requirements under cross compliance and apply to anyone who receives payments under Single Payment Scheme. GAECs set requirements for farmers in respect of soils, as well as maintaining a range of habitat and landscape features, which are characteristic of the Italian countryside. The GAEC standard retain terraces prohibits farmers the elimination of existing terraces, bounded downstream by a dry stone wall or a grassed cliff. This standard, made mandatory to any farm surface, had been introduced by Ministry of Agricultural, Food and Forestry Policies (Mipaaf) decree on Cross compliance up to end 2009 (rule 4.4) with the aim of ensuring a minimum level of habitat maintenance. Then, the following Decree 30125 of December 2009 (after the Health Check) maintained this standard (named standard 1.3) under the Rule 1 (measures for the protection of the soil) with the aim of ensuring the protection of soil from erosion. The most important difference between the two periods of application of the rule (before and after December 2009) lies in the very contrasting procedures regarding the field controls prescribed by Agency for Agricultural Payments (AGEA) and other regional Agencies for Agricultural payments to detect the infringements to this standard. 
In the first period, the infringement was detected in relation to increasing levels of the terrace degradation. In the second period, to date, the infringement only concerns the total elimination of terraces.

In the present work the standard retain terraces was evaluated in respect of its effectiveness in protecting soil from erosion, by considering increasing levels of degradation. That is because the research project EFFICOND ${ }^{1}$ that made this study possible, has been focused on the evaluation of the effectiveness of GAEC standard come into force since December 2009. Furthermore, the former criteria of detection of the infringements to the standard appear to be more effective in the protection of soil against erosion than the new ones. To retain terraces without considering their maintenance as a fundamental good agronomical practice is irrational for all to see, even the most inexperienced people.

\section{The Italian agricultural terraces}

In Italy terraces have always been present since ancient times. Dry stone wall terraces have been found in Liguria in archaeological excavations of sites of the Iron Age (1000 BC).

The maximum expansion of the terraces has occurred since the Middle Ages with the birth of Municipalities, to reach its peak in the eighteenth and nineteenth centuries. The driver that caused the expansion of the terraces is the need to increase agricultural crops on steep slopes due to demographic pressure. Terracing introduced agriculture in natural environments otherwise impossible to cultivate. The construction of terraces provided important opportunity of life in the hillsides and mountains, and also prevented the uncontrolled water runoff, reduced erosion and gave stability to natural slopes prone to landslides.

During the twentieth century, the expansion of the industrial economy and urbanization were crucial reasons for the depopulation of the countryside. In the second half of the twentieth century depopulation became a real escape from hilly and mountainous areas of Italy. This phenomenon led to the increase of hydrogeological disorder due to the abandonment of a correct water management in sloped lands to which the abandonment of terraced systems contributed negatively.

Nowadays, most of the terraced areas are subject to increasing degradation. This is because the labour, the instrument that for centuries has provided for their continuous monitoring and maintenance, is too expensive when compared to the gains that can be obtained in the sloping areas characterized by marginal economy. An exception is the sloped areas of high economic interest, especially those of particular value for viticulture and other specialized cultures, where the terraces are preserved and extended up to very high altitudes (Figure 1).

Among the different Italian systems of surface setting of fields for correct cultivation and water management, terracing has been always recognized as being very effective as for soil and landscape conservation (Bonardi, 2005; Ogrin, 2005). The United Nations defined terraced land as the most important system of organization of landscape in the Mediterranean region (UN, 2005) and expressed the need to protect them for their effectiveness to counteract desertification and land degradation.

In Europe the areas where terraces are present, especially along the Mediterranean coast, are characterized by very pronounced gradients (King et al., 2000) (Figure 2).

${ }^{1}$ EFFICOND: $($ EFF $=$ Effectiveness of environmental standards, $C O N D=$ Cross compliance $)$ is a CRA (Agricultural Research Council) project started in 2009 to meet the specific need of NRN (National Rural Network) to monitor and evaluate the effectiveness of environmental protection actions mandated by the CAP to national agricultural policy and implemented by the Regional Rural Development Plans (RDP). The main project objectives are the evaluation of GAEC standards implemented under cross compliance and the development of agrienvironmental indicators for nation-wide scenario analysis. The EFFICOND project involves 10 operational units with experimental fields located throughout the country.
In Italy terraces can be classified into two main groups: stone wall terraces (without binder) and earth terraces. In both systems terraces are distributed across the slope to obtain a series of flat surfaces easy to cultivate. In stone wall terraces the graded surfaces are supported downhill by dry stone walls. In the earth terraces the downhill edge is a cliff of compacted earth, covered by natural grass. A terraced slope is usually complemented by other structures as trails, canals and small buildings that increase the landscape value of the area.

Figures 3 and 4 shows two examples of terraces in Italy to which the standard retain terraces is addressed.

Some studies evaluated the terraced system in terms of slope stability (Inbar and Llerena, 2000; Schoorl and Veldkamp, 2001; Dorren and Rey, 2004; Koulouri and Giourga, 2006). In particular, some of them investigated the effect of rainfall on terrace stability in the Mediterranean climate. Heavy rainfalls occurring in spring and autumn have a significant role as regards terrace stability, because they expose the structural elements to strong mechanical stress (Durán Zuazo et al., 2005; Brancucci and Paliaga, 2006; Ramos et al., 2007).

One of the most interesting studies in the Italian territory was carried out in Liguria by Brandolini and Ramella (1998), who compared different types of landslides occurred on terraced lands characterized by contrasting morphological conditions, geological substratum and soil use. These authors grouped agricultural terraces into three main typologies (Figure 5): A) terraces set up on compact and permeable bedrock (cracked) with low risk of landslides; B) terraces set up on eluvial-colluvial deposits with moderate risk of landslides; C) Terraces set

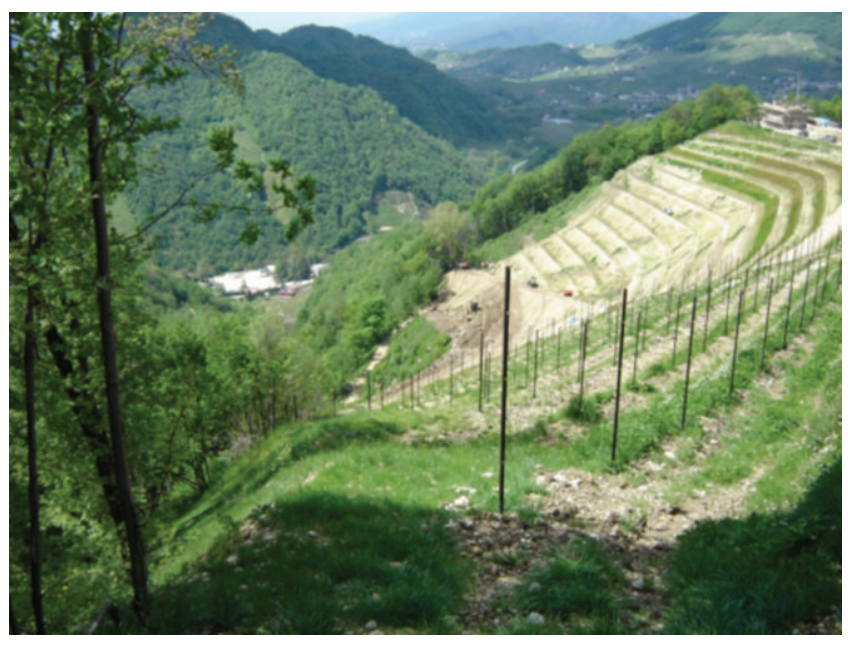

Figure 1. Earth terraces under construction in Veneto (in the Prosecco wine area).

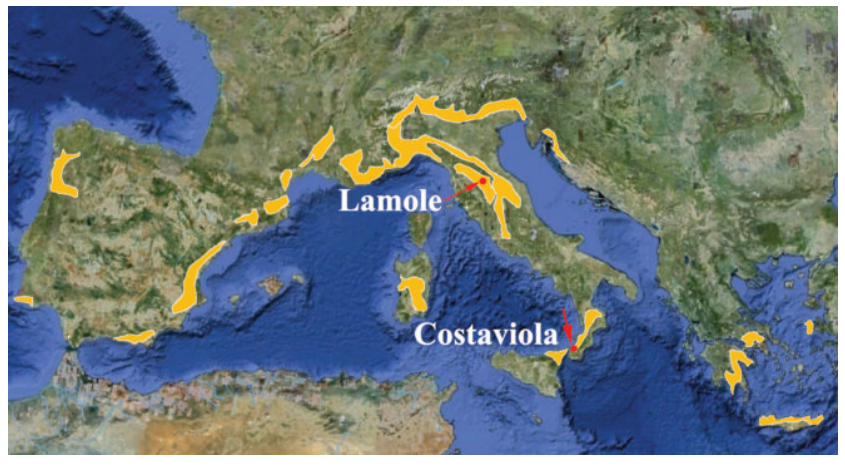

Figure2. Terraced land in Europe (in yellow) and location of the two study areas, Lamole (Tuscany) and Costaviola (Calabria). 
up on incoherent materials with high risk of landslide. This classification can help to understand that degradation of terraces can assume a very wide variety of forms ranging from a quick degradation to no degradation and with different dynamics, depending on site specific condition: climate, geology, morphology, seismicity, land use and management etc.. The most dangerous menace to terraces integrity due to abandonment of their maintenance by farmers is the loss of channel connectivity and, consequently, the loss of runoff regulation. This can lead to mass movement of the soil embanked by terraces. These movements, although very feeble, determine the loss of compaction of the stone walls or cliffs of terraces. Thus, in the presence of extreme rainfall events, the wall can collapse and severe landslides can occur. In general, when stone wall terraces are built on outcropping bedrock they last longer after abandonment of agriculture than other typology of terraces and maintain their effectiveness in controlling runoff water (Figures 6, 7 and 8). In very favorable conditions stone wall terraces, although abandoned, do not alter at all (Figure 6). In Terraces set up on incoherent materials the stones collapsed out of the wall usually

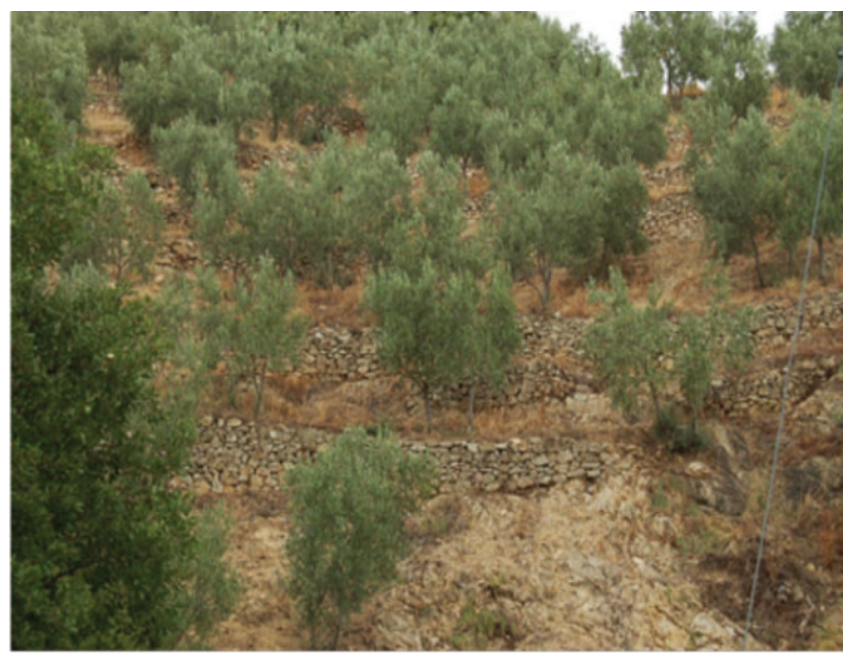

Figure 3. Stone wall terraces (Calabria).

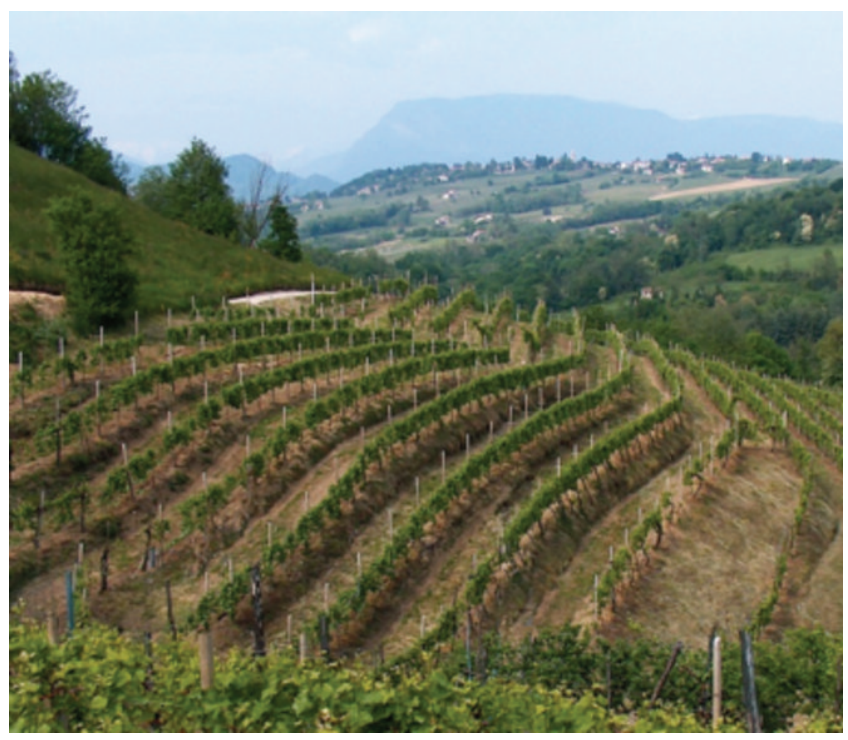

Figure 4. Earth terraces (Veneto).

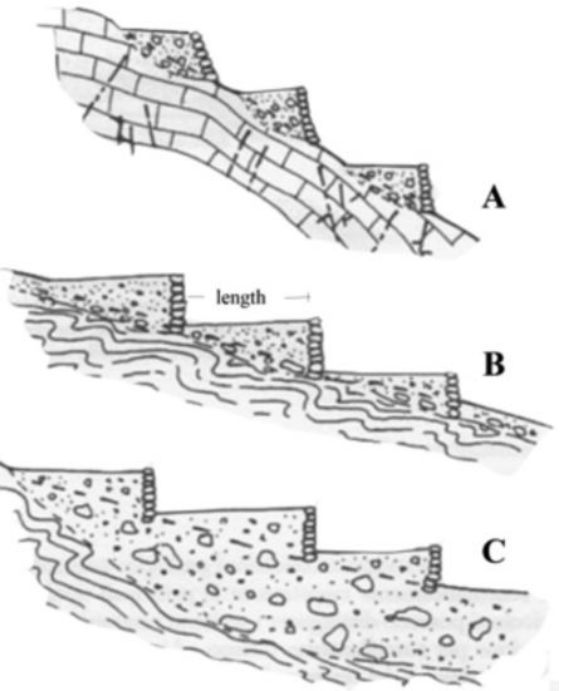

Figure 5. A), terraces set up on compact and permeable bedrock with low risk of landslides; B), terraces set up on eluvial-colluvial deposits with moderate risk of landslides; C), terraces set up on incoherent materials, with high risk of landslide (from Brandolini and Ramella, 1998, modified).

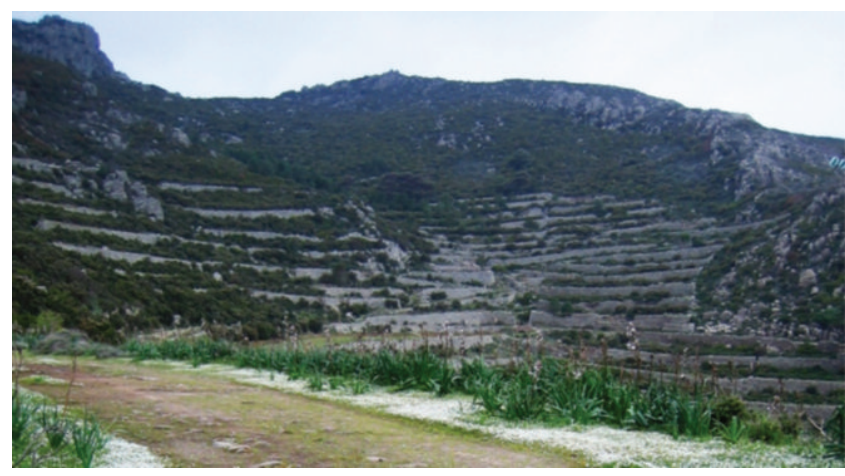

Figure 6. Stonewall terraces set up on compact bedrock at Capraia isle (Tyrrhenian sea) with shrubs and forest in evolution. Terraces were built by prisoners before the dismissing of the penitentiary. In this case the abandonment of agriculture did not lead to degradation of terraces. (Image by Andrea Gervasoni, 2009).

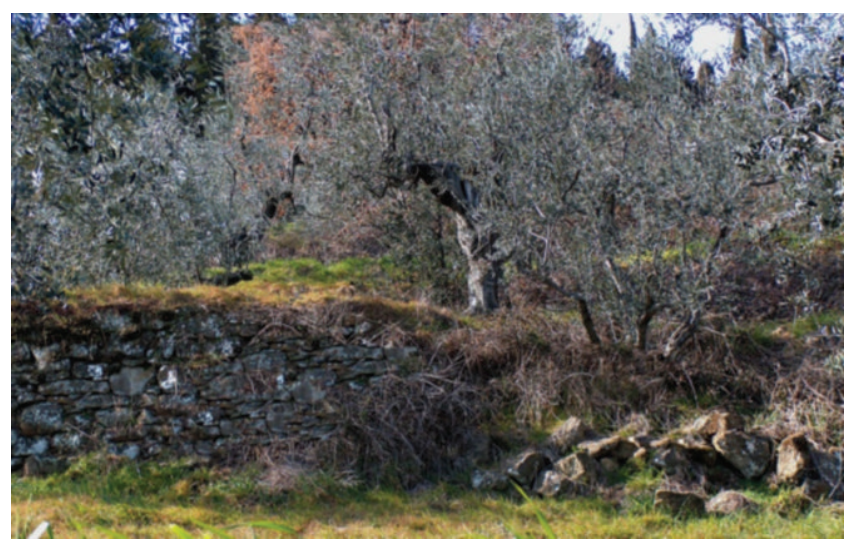

Figure 7. Stone wall terraces set up on incoherent colluvium (Fiesole, Tuscany). Agriculture is almost abandoned and degradation of terraces is going on, but the slope gradient of terraces is still sufficiently conserved. 
remain on site in the form of a heap; while in earth terraces the cliff zone is subject to gully erosion.

Lack of maintenance of terraces does not necessarily correspond to the abandonment of agriculture on terraced areas. The most dangerous condition is when the human presence completely lacks and even the more necessary repairs to stone wall or earth cliffs are not made.

In the majority of cases, the abandonment of terraces does not lead, in the short run, to a complete draw back of the slope to the antecedent morphology. The local gradient in the correspondence of plans of degraded terraces almost always remains lower than the average gradient of the slope (Figures 8, 9 and 10).

Finally, conservation of terraced systems assumes a major importance in terms of production of public goods and services as: i) decrease of risk of wildfire and erosion on bare soil after fire (Grove and Rackham, 2001); ii) conservation of the aesthetic value of landscape; iii) offsite effects related to reduction of peak runoff and flood risk as well as decrease in the amount of sediment that delivered to the river network (Bazzoffi, 2007).

\section{Materials and Methods}

The study concerned two sample areas with very contrasting soils, climatic conditions and cultural systems. Both areas are located in landscapes of very high historical and cultural value, forming significant parts of the catalog of Rural Historic Landscapes (Agnoletti, 2010) established by the Italian Ministry of Agricultural, Food and Forestry Policies (Figures 11, 12 and 13).

The sample area at Lamole is located in the famous Chianti vine area (Greve, Province of Florence). The area covers 700.82 ha, with an altitude of about $580 \mathrm{~m}$ above sea level. The average slope of terraced land is $29.7 \%$. The geological substratum of the Lamole area mainly consists of quartz turbidite sandstones (42\%), feldspar (27\%) and calcite (7\%), phyllosilicates (24\%) and silty shale, and marl in the south are yellow of Oligocene source, named Marne San Polo.

The Costaviola area (in the province of Reggio Calabria) is located on the Tyrrhenian coast of Calabria, in the municipalities of Palmi, Bagnara and Seminara, in the Province of Reggio Calabria. The area is almost entirely within the Costa Viola ZPS (Special Protection Area) and belongs to the SIC (Site of Community Importance) named Monte $\mathrm{S}$. Elia. The Costaviola study area is private land mostly located at altitudes ranging between 0 and $500 \mathrm{~m}$ above sea level. The average slope of terraced land is $59.8 \%$. This area is characterized by the longevity of some old vines cultivated as high pergolas or small tree. Even today, due to the high steepness of the land, the transport of grapes is made through picturesque monorail suspended in the air. The area, extending to $764.73 \mathrm{ha}$, is located on a geological substrate (mainly amphibole and mica schist with pegmatite veins and jalomicte), while inland areas have a substrate made of reddish clay sand and pebble conglomerates of crystalline sand-clay cement.

The goal of this work was to evaluate the effectiveness of the GAEC standard retain terraces in terms of soil erosion control. For this purpose it was necessary to compare soil erosion risk in conserved vs. degraded terraced systems. In case of infringement to GAEC standard retain terraces, the AGEA rules, since December 2009, have made the recognition of three indices of verification mandatory, as follows: i) extent, based on the area involved by the infringement; ii) severity, based on the extent of offsite effects; iii) duration (the level of this indicator is calculated in relation to assessment of permanence of the damages).

In this study, the indexes of infringement were made correspondent to 5 conditions of terrace maintenance and percentages of degradation (Table 1).
Since there are no experimental data on this topic, soil erosion risk $\left(\mathrm{Mg} \cdot \mathrm{ha}^{-1} \cdot \mathrm{yr}^{-1}\right)$ of conserved and degraded terraced systems was assessed by a scenario analysis. To perform the analysis the USLE model developed by Wischmeier and Smith $(1965,1978)$ was applied.

For each study area (Lamole and Costaviola) soil erosion risk was estimated five times, each of which corresponds to the hypothesis of a different percentage of degradation, as reported in Table 1.

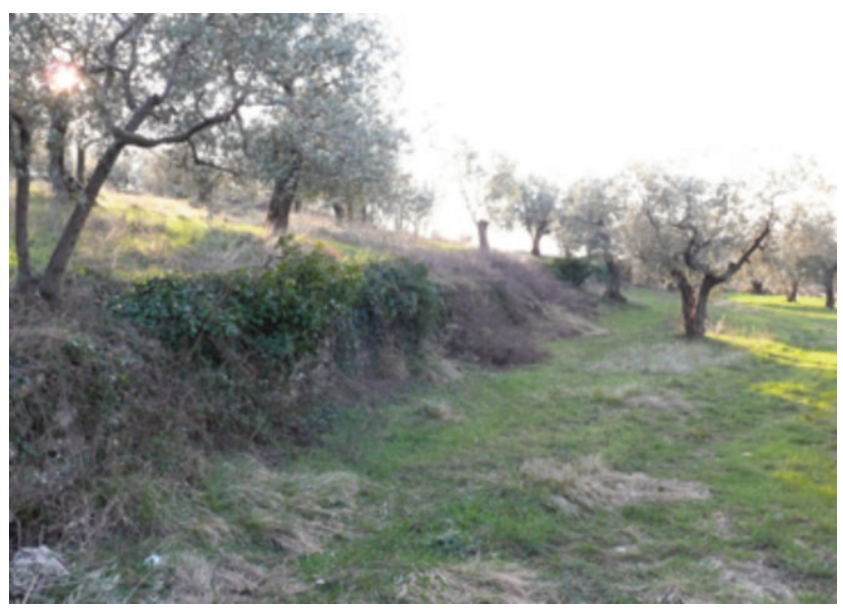

Figure 8. Example of a stone wall almost totally collapsed. Although they are degraded, terraces still maintain a residual function on soil erosion control (Prato, Tuscany).

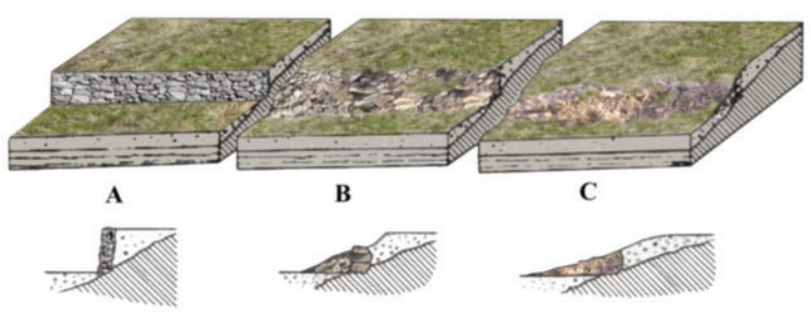

Figure 9. Progressive degradation of stone wall terraces. (A) conserved; (B) damaged; (C) eliminated.

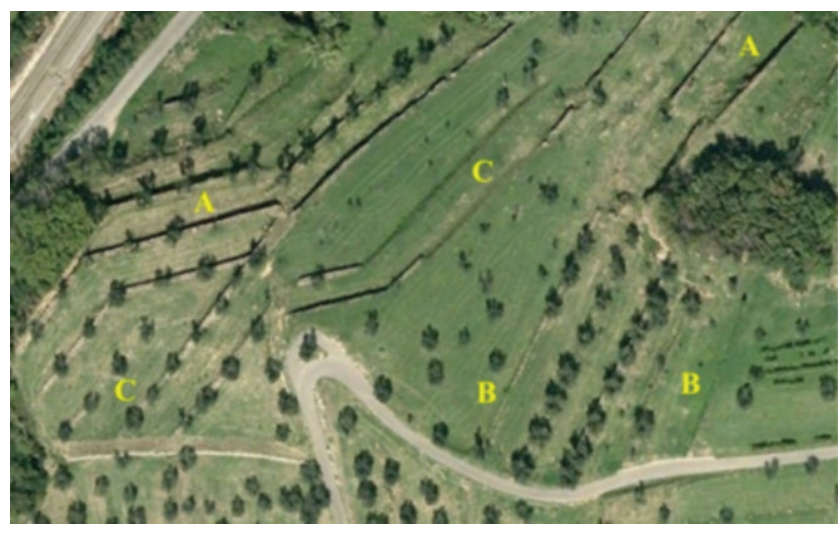

Figure 10. Aerial picture of different levels of terrace degradation according to the schematic drawing of Figure 9 (Prato, Tuscany). 
Table 1. Intensities of terrace degradation adopted in the scenario analysis.

\begin{tabular}{lcccc} 
Condition & \multicolumn{2}{c}{ Verification indexes AGEA } & $\begin{array}{c}\text { Percentage of } \\
\text { degradation } \\
\text { (decimal) }\end{array}$ \\
Extent & Severity & Duration & None & 0 \\
Partially damaged & 1 & 1 & 1 & 0.1 \\
\hline Very damaged & 1 & 1 & 1 & 0.3 \\
Partially removed & 3 & 3 & 3 & 0.5 \\
\hline Removed & 5 & 5 & 5 & 1
\end{tabular}

For each repetition, the weighted average of soil erosion risk for each land use was calculated as follow:

$$
\bar{x}=\frac{\sum_{i=1}^{n} w_{i} \cdot x_{i}}{\sum_{i=1}^{n} w_{i}}
$$

where:

$\overline{\mathrm{X}}=$ weighted average of soil erosion risk $\left(\mathrm{Mg} \cdot \mathrm{ha}^{-1} \cdot \mathrm{yr}^{-1}\right)$ for each land use in the selected study area

$\mathrm{n}=$ number of polygons (terraced) for each land use in the area

$\mathrm{w}_{\mathrm{i}}=$ area (ha) of the $\mathrm{i}^{\text {th }}$ polygon

$\mathrm{x}_{\mathrm{i}}=$ specific soil erosion risk $\left(\mathrm{Mg} \cdot \mathrm{ha}^{-1} \cdot \mathrm{yr}^{-1}\right)$ for the $\mathrm{i}^{\text {th }}$ polygon

The USLE model estimates erosion by means of the following empirical equation:

$$
A=R \text { K L S C P }
$$

where:

$\mathrm{A}=$ average annual soil loss $\left(\mathrm{Mg} \mathrm{ha}^{-1} \mathrm{yr}^{-1}\right)$

$\mathrm{R}=$ rainfall erosivity factor $\left(\mathrm{MJ} \mathrm{mm} \mathrm{ha} \mathrm{m}^{-1} \mathrm{~h}^{-1} \mathrm{yr}^{-1}\right.$ )

$\mathrm{K}=$ soil erodibility factor $\left(\mathrm{Mg}\right.$ ha $\left.\mathrm{h}^{-1} \mathrm{MJ}^{-1} \mathrm{~mm}^{-1}\right)$

$\mathrm{L}=$ slope length factor (dimensionless)

$\mathrm{S}=$ slope steepness factor (dimensionless)

$\mathrm{C}=$ cover and management factor (dimensionless)

$\mathrm{P}=$ support practice aimed at erosion control factor (dimensionless)

The revised USLE (RUSLE) by Renard et al. (1997) was not applied in this study because the SL factor was not derived automatically from the Digital Elevation Model (DEM). For the two study areas a photo interpretation of aerial photos was made to define the terraced areas and their soil uses. Digital orthophotos AIMA (50 cm resolution) in natural colors were used, dated 2007 and 2006 for Lamole and Costaviola areas, respectively. To apply the USLE model the layers of rainfall erosivity and soil erodibility were acquired in a Geographic Information System (GIS). The layers used in the application of the methodology are: i) Digital Elevation Model (DEM $20 \times 20 \mathrm{~m}$ ) of the national territory (Ministry for the Environment, Land and Sea); ii) rainfall erosivity $(75 \times 75 \mathrm{~m})$, calculated by averaging the results of 7 algorithms applied to the mean monthly rainfall data of the Italian network of raingauges (Bazzoffi, 2007); iii) soil erodibility (calculated from soil texture data of the BADASUOLI project database (Costantini, personal communication). The LS topographic factor was calculated by multiplying the $\mathrm{L}$ and $\mathrm{S}$ factors obtained through the formulas of the USLE model (Wischmeier and Smith, 1978) as follows:

$$
\mathrm{L}=[(\lambda / 2.2798) / 72.6]^{\mathrm{m}}
$$

$\mathrm{S}=65.41 \sin ^{2} \theta+4.56 \sin \theta+0.065$
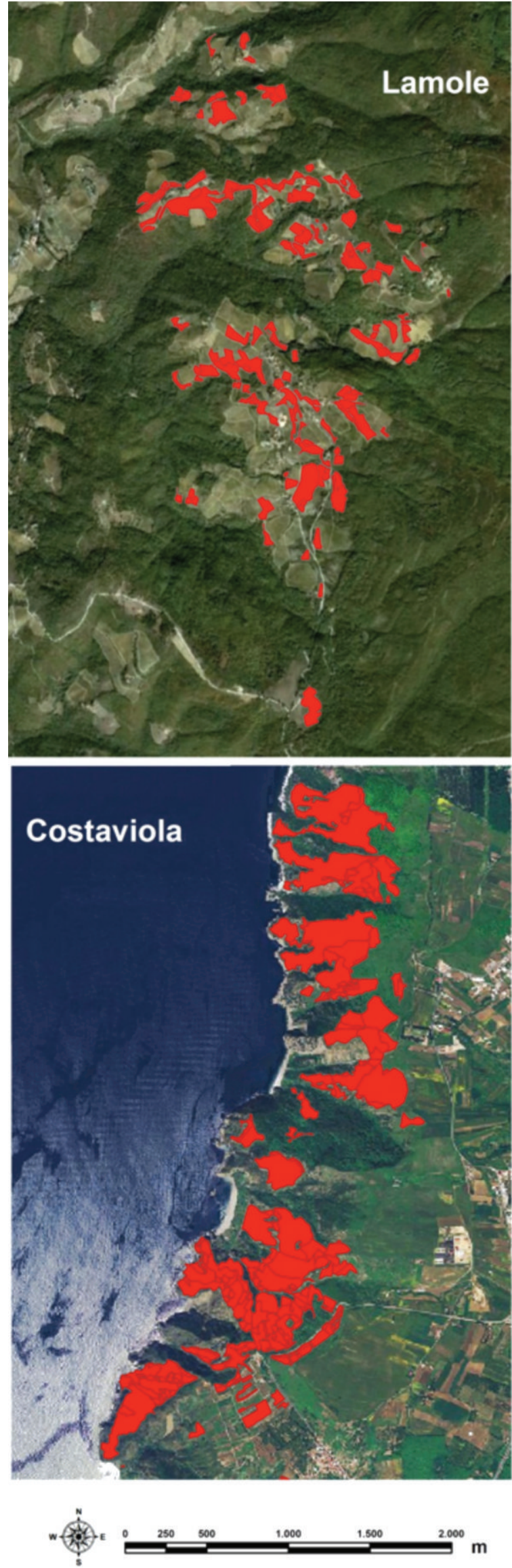

Figure 11. Terraced land (in red) in the two study areas. 
where $\lambda=$ slope length (meters)

$\theta=$ angle of the slope (sexagesimal degree)

$\mathrm{m}=0.5$ if the percent slope is 5 or more, 0.4 on slopes of 3.5 to $4.5 \%$, 0.3 on slopes of 1 to $3 \%$, and 0.2 on uniform gradients of less than $1 \%$.

To growing intensity of degradation a progressive loss of efficacy of terraces was attributed by increasing the values of the LS factor of USLE (length and slope) in relation with the local increase, between contiguous terraces, of the gradient and length of the slope.

Clearly, the degradation process of a terrace is something very complex and highly variable depending on various factors. To simulate this process some assumptions were made in order to make possible to apply the calculation under GIS, as follows: i) it was assumed that the local slope length increases along the slope due to the increasing interconnection of contiguous terraces, according to increasing percentages of degradation (progressive annulment of the isolating effect, with respect to runoff, exerted by stone walls); ii) It was assumed that degradation increases the gradient of terraces, due to soil erosion and landslides, which draw back the slope to its natural morphology; iii) it was assumed that the maximum degree of degradation (100\%) corresponds to the total annulment of one every two terraces.

The third assumption was adopted on the basis of the aforesaid considerations, namely: lack of maintenance of terraces does not necessarily correspond to the abandonment of agriculture and almost never leads to a complete draw back of the slope to the antecedent morphology. Therefore, the gradient of degraded terraces almost always remains lower than the average original gradient of the slope.

For each terraced polygon, the calculation of soil erosion risk ( $\mathrm{Mg}$. $\mathrm{ha}^{-1} \cdot \mathrm{yr}^{-1}$ ) was made over a standard hydrological unit of interconnected terraces after degradation. The degree of interconnection was expressed, as mentioned, in terms of increase of length and gradient of a terrace.

To fully conserved terraces the hydrologic unit corresponds to one conserved terrace; which means no connection between two adjacent terraces. To totally degraded terraces (removed) the hydrologic unit corresponds to a fully interconnection of two contiguous terraces. To intermediate degrees of degradation the hydrological unit assumes intermediate values of length and gradient between the two extremes.

In Figure 14 a schematic drawing of minimum and maximum degradation is shown. In the scenario analysis (soil erosion risk vs. intensities of degradation), the length of the hydrological unit was increased by using the following formula:

$$
\mathrm{L}_{\mathrm{h}}=\mathrm{L}_{\mathrm{tor}}+\left(\mathrm{L}_{\mathrm{tor}} \cdot \mathrm{X}\right)
$$

where:

$\mathrm{L}_{\mathrm{h}}=$ inclined length of an hydrological unit $(\mathrm{m}): \sqrt{\left(\mathrm{h}_{\mathrm{t}}{ }^{2}+\mathrm{L}_{\mathrm{tor}}{ }^{2}\right)}$

$\mathrm{L}_{\text {tor }}=$ topographic length of a conserved terrace $(\mathrm{m}): \mathrm{L}_{\mathrm{tor}}=\left(100-\mathrm{L}_{\mathrm{stw}}\right) / \mathrm{N}_{\mathrm{t}}$ $\mathrm{N}_{\mathrm{t}}=$ number of terraces per $100 \mathrm{~m}$ of topographic length: $\left(\mathrm{G}_{\mathrm{or}} / \mathrm{h}_{\mathrm{t}}\right)$

$\mathrm{G}_{\mathrm{or}}=$ original gradient (\%) of the slope, considered without terraces (from DEM)

$\mathrm{h}_{\mathrm{t}}=$ mean height of a stonewall (m)

$\mathrm{L}_{\mathrm{stw}}=$ total topographic length $(\mathrm{m})$ occupied by the stonewalls per 100 m length: $\left(\mathrm{N}_{\mathrm{t}} \cdot \mathrm{W}_{\mathrm{t}}\right)$

$\mathrm{W}_{\mathrm{t}}=$ mean width of a stonewall measured at the point of its maximum thickness.

$\mathrm{X}=$ percentage of degradation (decimal, from Table 1).

The gradient of the hydrological unit was calculated through the following formula:

$$
\mathrm{G}_{\mathrm{t}}=\mathrm{G}_{\mathrm{ct}}+\left\{\left[\left(\mathrm{h}_{\mathrm{t}} /\left(2 \cdot \mathrm{L}_{\mathrm{h}}\right)\right]-\mathrm{G}_{\mathrm{ct}}\right)\right\} \cdot \mathrm{X}
$$

where:

$\mathrm{G}_{\mathrm{t}}=$ gradient (\%) of an hydrological unit

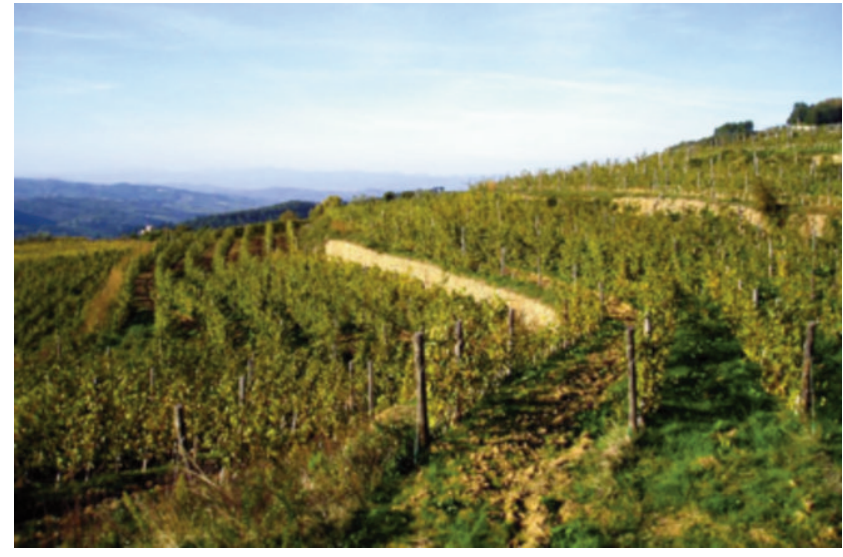

Figure 12. Terraces in the Lamole study area.

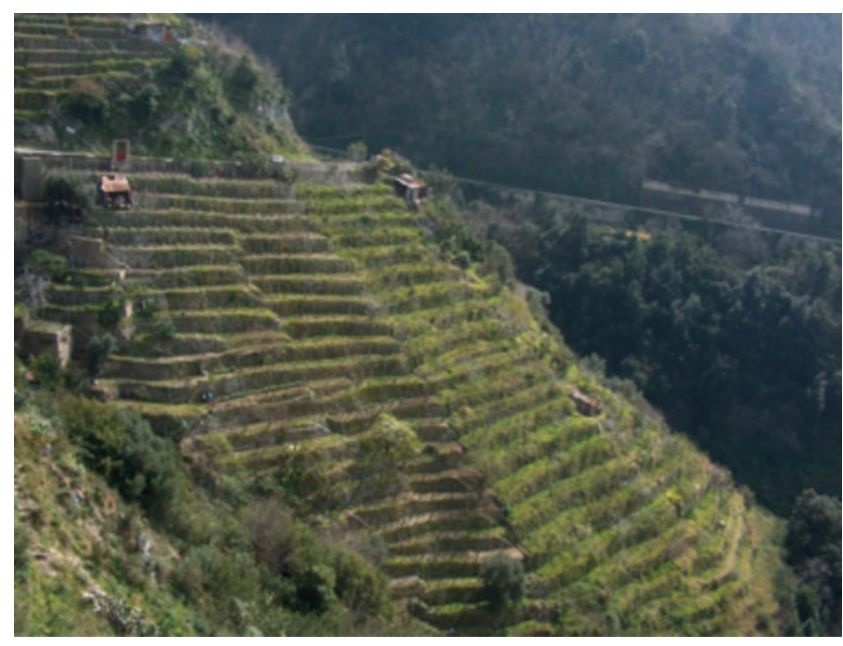

Figure 13. Terraces in the Costaviola study area.

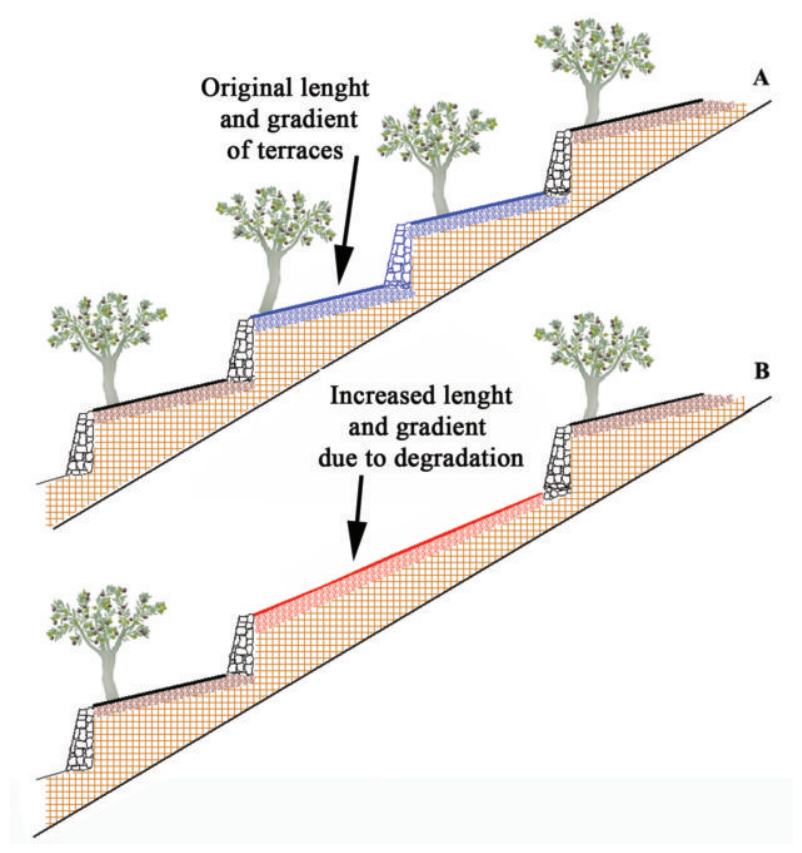

Figure 14. Schematic drawing of minimum and maximum degradation of terraces. A) $0 \%$ degradation (conserved terraces). B) $100 \%$ degradation (annulment of one every two stonewalls). 
$\mathrm{G}_{\mathrm{ct}}=$ gradient (\%) of a conserved terrace, according to local use. In this study $3 \%$ was adopted for both areas.

$\mathrm{h}_{\mathrm{t}} ; \mathrm{L}_{\mathrm{h}} ; \mathrm{X}=$ as reported above

The gradient $\left(\mathrm{G}_{\mathrm{t}}\right)$ of the hydrological unit varies in a range between the original gradient of a conserved terrace and the gradient obtained by deleting a terrace every two, as shown in Figure 14.

\section{Results and Discussion}

Results of the scenario analysis for the two study areas are shown in Table 2. To evaluate the effectiveness of GAEC standard retain terraces in relation to erosion, it is important to consider the fact that soil erosion tolerance (T) cannot be fixed in relation to a precise threshold value $\left(\mathrm{Mg} \cdot \mathrm{ha}^{-1} \cdot \mathrm{yr}^{-1}\right)$ only, assumed valid for all soils and situations. The acceptable limit should be set in consideration of the hazard, vulnerability and value that is threatened by erosion, taking into account, therefore, the different nature and fragility of the soil, the economic value of the land and the off-site effects of erosion (Bazzoffi, 2009).

Despite the complexity of these issues, the rural development policies need a drastic simplification of the criteria to know whether the GAEC standard retain terraces is effective or not and, consequently, to decide whether it is necessary to modify the standard or the typology of land eligible for the allocation of monetary resources.
The best compromise can be found by adopting the limit of 11.2 $\mathrm{Mg} \cdot \mathrm{ha}^{-1} \cdot \mathrm{yr}^{-1}$. This value, which was defined in the United States by the Natural Resources Conservation Service (USDA-NRCS, 1999), is largely adopted all over the world in territorial risk analysis. On the basis of this threshold, Table 2 shows in red the values of erosion risk $>11.2 \mathrm{Mg} \cdot \mathrm{ha}^{-1} \cdot \mathrm{yr}^{-1}$ in the study areas, according to different soil uses and type of degradation of terraces.

Table 3 shows the percent of soil uses, in the two study areas, where the scenario analysis predicts a soil erosion risk that exceeds the tolerance limit, according to different soil uses and type of degradation of terraces.

Figure 15 only examines the results obtained for the land uses: i) forest and ii) abandoned areas with natural vegetation in evolution. In both areas, the scenario analysis shows that forest on totally degraded terraces is able to decrease erosion well below the tolerance threshold of $11.2 \mathrm{Mg} \cdot \mathrm{ha}^{-1} \cdot \mathrm{yr}^{-1}$, in the same manner as conserved terraces do for other soil uses. At Lamole, the natural vegetation in evolution on completely degraded terraces is able to decrease erosion below the tolerance threshold. On the contrary, at Costaviola, on the same soil use and level of terrace degradation, soil erosion remains above the tolerance threshold. This difference can be explained by considering that the average natural gradient (the slope considered without the presence of terraces) of areas with natural vegetation in evolution is 71.8 $\%$ for Costaviola and 29.6\% for Lamole. Based on these findings, it is possible to argue that terraces, although degraded, continue to play a
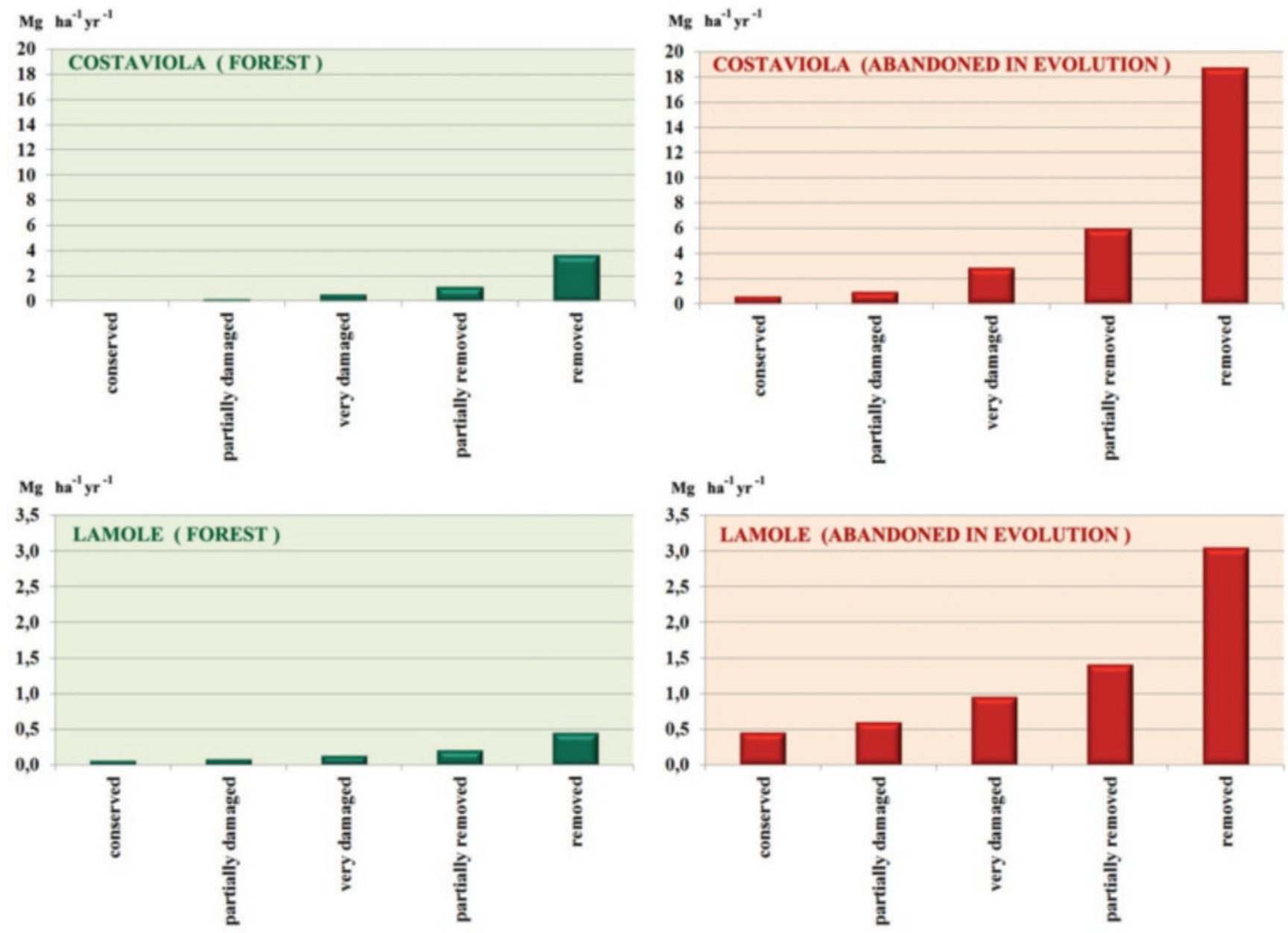

Figure 15. Soil erosion risk for the soil uses: forest and abandoned areas with natural vegetation in evolution, according to different levels of terrace degradation in the two study areas. 
Table 2. Scenario analysis of soil erosion $\left(\mathrm{Mg} \cdot \mathrm{ha}^{-1} \cdot \mathrm{yr}^{-1}\right)$ in the study areas, Costaviola and Lamole. Erosion risk values above the USDA limit $\left(11.2 \mathrm{Mg} \cdot \mathrm{ha}^{-1} \cdot \mathrm{yr}^{-1}\right)$ are shown in italics.

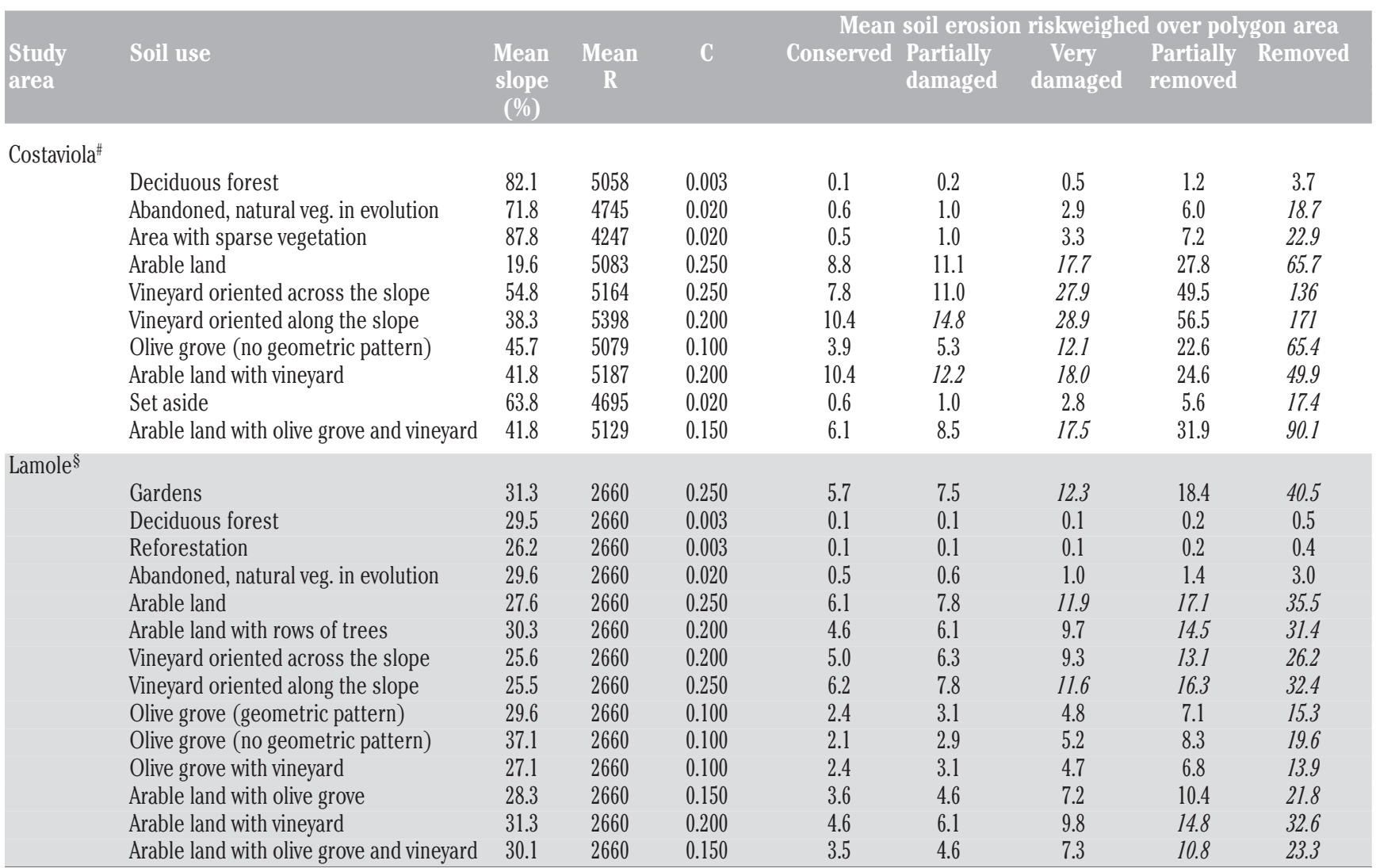

${ }^{\circ}$ Gradient of the natural slope considered without terraces; ${ }^{\sharp}$ Costaviola $\mathrm{K}$ factor, 0.04 ; $\$$ Lamole $\mathrm{K}$ factor, 0.034 .

Table 3. Percentage of soil uses, in the two study areas, where the scenario analysis predicts a soil erosion risk that exceeds the tolerance limit, according to different soil uses and type of degradation of terraces.

\begin{tabular}{lccccc} 
Condition & Extent & $\begin{array}{c}\text { Verification indexes AGEA } \\
\text { Severity }\end{array}$ & Duration & $\begin{array}{c}\text { Percentage of soil uses over tolerable erosion } \\
\text { Lamole }\end{array}$ \\
Conserved & None & None & None & $0 \%$ & $0 \%$ \\
Partially damaged & Low & High & High & $0 \%$ & $20 \%$ \\
\hline Very damaged & Medium & High & High & $27 \%$ & $60 \%$ \\
Partially removed & Medium & High & High & $46 \%$ & $60 \%$ \\
\hline Removed & High & High & High & $72 \%$ & $90 \%$ \\
\hline
\end{tabular}

role in the protection of soil against erosion in abandoned areas. Thus, they continue to exert a valuable environmental function in terms of production of public goods and services; in particular, in the decrease of hydrogeological risk.

\section{Conclusions}

The scenario analysis enables to affirm that the maintenance of terraces is a very effective tool to decrease soil erosion within the threshold of tolerability. Thus, the GAEC standard retain terraces of cross compliance has been demonstrated to be useful with regard to the main environmental issues of Annex Annex IV of Council Reg. No 1782/2003 of soil erosion control and avoid the deterioration of habitats.

\section{References}

Agnoletti M., 2010. Paesaggi Rurali Storici. Per un catalogo nazionale. Laterza Ed., Bari, Italy.

Bazzoffi P., 2007. Erosione del suolo e sviluppo rurale: fondamenti e manualistica per la valutazione agroambientale. Edagricole, Bologna, Italy.

Bazzoffi P., 2009. Soil erosion tolerance and water runoff control: minimum environmental standards. Reg Environal Change 9:169-179.

Bazzoffi P., Abbattista F., Vanino S., Napoli R., 2006. The new Italian Atlas of sediment yield from basins. Page 493 in Proc. 18th World Congr. Soil Science, Philadephia, PA, USA.

Bonardi L., 2005. Nuove funzionalità per i paesaggi terrazzati. In D. Trischitta (ed.) Il paesaggio terrazzato: un patrimonio geografico antropologico, architettonico, agrario, ambientale. Edizioni Città del Sole, Reggio Calabria, Italy, pp 59-99.

Brancucci G., Paliaga G., 2006. The hazard assessment in a terraced 
landscape: preliminary result of the Liguria (Italy) case study in the Interreg III ALPTER Project. In: F. Nadim, R. Pöttler, H. Einstein, H. Klapperich, S. Kramer (eds.), Paper no. 16, ECI Conf. on Geohazards, Lillehammer, Norway.

Brandolini P., Ramella A., 1998. Processi erosivi e fenomeni di dissesto su versanti terrazzati nelle valli genovesi. In: M.G. Grillotti and L. Moretti (eds.) Atti Convegno Geografico Internazionale: I valori dell'agricoltura nel tempo e nello spazio, Rieti, 1-4 novembre 1995. pp 839-854, Brigati Ed., Genova, Italy.

Dorren L., Rey F., 2004. A review of the effect of terracing on erosion. In: S. van Asselen, C. Boix-Fayons and A. Imeson (eds.) pp 97-108, Briefing papers of the 2nd SCAPE Workshop, Cinque Terre, Italy.

Durán Zuazo V.H., Aguilar Ruiz J., Martínez Raya A., Franco Tarifa D., 2005. Impact of erosion in the taluses of subtropical orchard terraces. Agr. Ecosyst. Environ. 107:199-210.

Grove A.T., Rackham 0., 2001. The Nature of Mediterranean Europe: an ecological history. Yale University Press, New haven, CT, USA.

Inbar M., Llerena C.A., 2000. Erosion Processes in High Mountain Agricultural Terraces in Peru. Mt. Res. Dev. 20:72-79.

King, R., Cori, B., Vallega, A., 2000. Unity, diversity and the challenge of sustainable development: an introduction to the Mediterranean. In: R. King, P. de Mas and J. Mansvelt Beck (eds.) Geography, Environment and Development in the Mediterranean. Sussex Academic Press, Eastbourne, UK.

Koulouri M., Giourga Chr., 2006. Land abandonment and slope gradient as key factors of soil erosion in Mediterranean terraced lands. Catena 69:274-281.

US Department of Agriculture, Natural Resources Conservation Service, 1999. National Soil Survey Handbook, title 430-VI.
Available from: http://soils.usda.gov/technical/handbook/

Ogrin D., 2005. Mediterranean landscapes: contribution to a better management. Report commissioned by Priority Actions Programme. Available from: http://www.pap-thecoastcentre.org/ Landscape_Report-OGRIN.pdf

Ramos M.C., Cots-Folch R., Martinez-Casanovas J.A., 2007. Sustainability of modern land terracing for vineyard plantation in a Mediterranean mountain environment. The case of the Priorat region (NE Spain). Geomorphology 86:1-11.

Renard K.G., Foster G.R., Weesies G.A., McCool D.K., Yoder D.C., 1997. Predicting Soil Erosion by Water: A guide to conservation planning with the Revised Universal Soil Loss Equation (RUSLE). USDA, Agricultural Handbook No. 703, Government Printing Office, Washington, DC, USA.

Schoorl J.M., Veldkamp A., 2001. Linking land use and landscape process modelling: a case study for the Álora region (south Spain). Agr. Ecosyst. Environ. 85:281-292.

United Nation, 2005. Promotion of Traditional Knowledge. Compilation of UNCCD documents and reports from 1997 to 2003. Available from: http://www.unccd.int/ (Accessed on 14 October 2006).

Wischmeier W.H., Smith D.D., 1965. Predicting rainfall erosion losses from cropland east of the Rocky Mountains - guide for selection of practices for soil and water conservation. USDA, Agriculture Handbook No. 282, Government Printing Office, Washington, DC, USA.

Wischmeier W.H., Smith D.D., 1978. Predicting rainfall erosion losses A guide for conservation planning. USDA, Agriculture Handbook No. 537, Government Printing Office, Washington, DC, USA. 